\title{
Pseudocercospora holmskioldiae and Cercospora apii associated with foliar spots on Holmskioldia sanguinea in Brazil
}

\author{
Eraclides M. Ferreira ${ }^{1} \&$ Dartanhã J. Soares ${ }^{1}$ \\ Departamento de Fitopatologia, Universidade Federal de Viçosa, CEP 36570-000, Viçosa, MG, Brazil, \\ e-mail: dartjs@yahoo.com.br
}

Autor para correspondência: Dartanhã J. Soares

\begin{abstract}
RESUMO
Pseudocercospora holmskioldiae e Cercospora apii associadas a manchas foliares em Holmskioldia sanguinea no Brazil

Durante os anos de 2004-2006, observou-se em plantas de Holmskioldia sanguinea (Verbenaceae), cultivadas no Campus da Universidade Federal de Viçosa (UFV) a ocorrência de manchas foliares. As estruturas fúngicas presentes nas lesões foram examinadas e corresponderam a Cercospora apii e Pseudocercospora holmskioldiae. Este é o primeiro relato destes fungos associados a $H$. sanguinea no Brasil.
\end{abstract}

During the years 2004-2006 were observed in the campus of Universidade Federal de Viçosa, Minas Gerais, Brazil, leaves of the ornamental plant Holmskioldia sanguinea Retz. (Verbenaceae), showing necrotic foliar spots. The symptoms were observed, during the three years, always in the dry season between May until mid-August. Associated to the spots two distinct cercosporoid fungi were found, one belonging to Cercospora and other to Pseudocercospora. Samples of spotted leaves were collected, examined under a stereomicroscope and dried in a herbarium press. Voucher specimens were deposited in the herbarium of Universidade Federal de Viçosa (Herbarium VIC) with the accession numbers: VIC 30493 and VIC 30494. Slides with fungal structures obtained by free hand section and scratching, were mounted using lactophenol and sealed with varnish nail. Observations, measurements and line drawings were prepared using an Olympus BX 51 light microscope, fitted with a drawing tube and an Olympus E-330 digital camera. Measurements of taxonomically relevant structures were made at $\times 1000$ magnification. The Cercospora species was identified as Cercospora apii Fres. emend. Crous \& Braun. This fungus was described earlier on $H$. sanguinea as Cercospora holmskioldiae Lall \& Gill from India (Lall \& Gill, Indian Phytopath. 15:243, 1963), but according to Crous \& Braun (Mycosphaerella and its anamorphs: 1. Names published in Cercospora and Passalora. 2003) it is now considered a synonym of $C$. apii, also reported on $H$. sanguinea in Cuba and Venezuela. The Pseudocercospora had the following morphology: Leaf spots amphigenous, necrotic, circular to irregular, sometimes confluents, $0.5-14 \times 0.5-8.9 \mathrm{~mm}$, brown to dark brown, surrounded by a distinct darker border, occasionally with a chlorotic halo. Spermogonium formed in the substomatal chamber, subglobose; spermatia cylindrical to ellipsoid, $2-3 \times 1 \mu \mathrm{m}$, hyaline. Stromata none or well-developed, arising from the substomatal chamber or formed over the spermogonium, immerse to erumpent, brown to dark brown, 25-62 × 17.5-50 $\mathrm{m}$; Internal Mycelium pale brown, 1.5-4 $\mu \mathrm{m}$ diam., septate, branched, smooth. Conidiophores hypophyllous, rarely epiphyllous, arising through the stomata in loosely fascicules or from stromata as dense fascicules, straight to tortuous, sometimes branched, 13-35 $\times 2.5-3.5 \mu \mathrm{m}, 0-4$-septate, brown at the base, paler toward the apex, thin-walled, smooth. Conidiogenous cells terminal, integrated, 5-12.5 × 1.5-3.5 $\mu \mathrm{m}, 0-3$ geniculate, subhyaline. Conidiogenous loci not darkened, unthickened. Conidia, solitary, subcylindrical to obclavate, straight to slightly curved, $15-57.5 \times 2-3.5 \mu \mathrm{m}, 1-6$ septate, subhyaline to pale olivaceous, base obconically truncate to truncate, apex rounded to obtuse, thin-walled, smooth (Fig. 1). These morphological characteristics permit identification of the fungus as Pseudocercospora holmskioldiae C. Nakash. \& Meeboon, recently described from Thailand (Nakashima et al., Fungal Div. 26:257, 2007). C. apii and P. holmskioldiae are, apparently, the first fungi signed on H. sanguinea in Brazil.

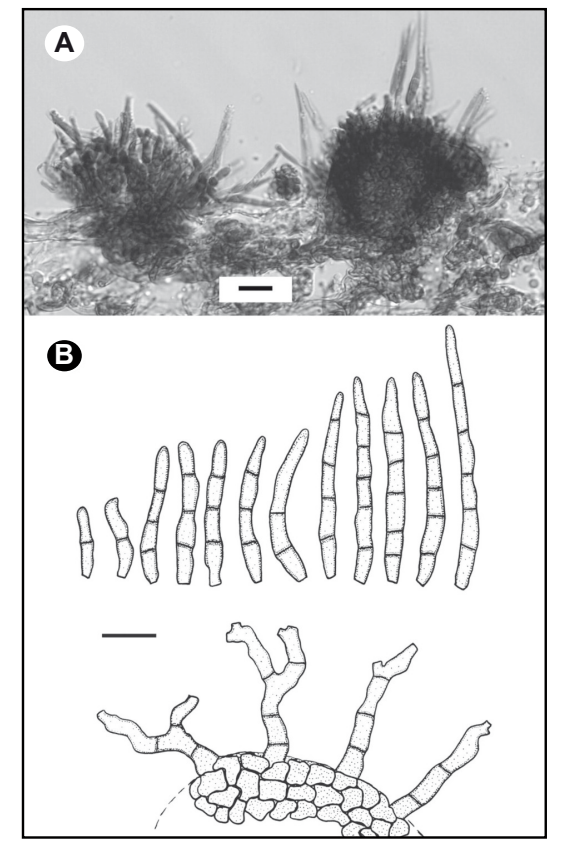

FIG. 1 - Pseudocercospora holmskioldiae on Holmskioldia sanguinea. a. Photomicrography showing a transversal section of stromata. Scale bar $=20 \mu \mathrm{m} ; \mathbf{b}$. Line drawing showing the conidia and a partial represented stromata to show the morphology of conidiophores. Scale bar $=10 \mu \mathrm{m}$. 